Geliş Tarihi:

08.07.2020

Kabul Tarihi:

05.05.2021

Yayımlanma Tarihi:

25.06.2021
Kaynakça Gösterimi: Bilginer-Özsaatcı, F. G. (2021). Markalarda yaşanan olumsuz durumların elektronik ağızdan ağıza iletişime (E-Wom) yansımaları: Pegasus örneği. İstanbul Ticaret Üniversitesi Sosyal Bilimler Dergisi, 20(40), 176-196. doi: 10.46928/iticusbe.766565

\title{
MARKALARDA YAŞANAN OLUMSUZ DURUMLARIN ELEKTRONIKK AĞIZDAN AĞIZA İLETIŞIME (E-WOM) YANSIMALARI: PEGASUS ÖRNEĞİ
}

\author{
Araştırma
}

Fatma Gül Bilginer Özsaatc1

Sorumlu Yazar (Correspondence)

Hasan Kalyoncu Üniversitesi

fatmagul.bilginer@hku.edu.tr

Fatma Gül Bilginer Özsaatc1, Hasan Kalyoncu Üniversitesi işletme bölümünde doktor öğretim üyesidir. İyi derecede İngilizce bilen yazar pazarlama, marka, marka stratejileri ve girişimcilik alanında çalışmalarını sürdürmektedir. Farklı dillerde kitap bölümleri, ulusal ve uluslararası dergilerde hakemlik tecrübesi, uluslararası kongrelerde bildirileri ve editörlük tecrübesi bulunmaktadır. 


\section{MARKALARDA YAŞANAN OLUMSUZ DURUMLARIN ELEKTRONIK AĞIZDAN AĞIZA İLETIŞíME (E-WOM) YANSIMALARI: PEGASUS ÖRNEĞİ}

Fatma Gül Bilginer Özsaatcı

fatmagul.bilginer@hku.edu.tr

\section{ÖZET}

Amaç: $\mathrm{Bu}$ çalışmanın amacı, markaların yaşadığı olumsuz durumların elektronik ağızdan ağıza iletişimi (eWOM) nasıl etkilediğini belirlemektir.

Yöntem: Çalışmada nitel araştırma tasarımlarından örnek olay yönteminden yararlanılarak, Pegasus havayollarının yaşamış olduğu uçak kazası neticesinde paylaştığı özür mesajına yapılan yorumlar analiz edilmiştir. Analizde kullanılacak yorumlar için Türkiye'de en çok kullanılan sosyal ağ sitelerinden biri olan İnstagram tercih edilmiş ve 1351 kullanıcı yorumu analiz edilmiştir

Bulgular: Analiz neticesinde oluşan 42 tema 10 kategori altında toplanmıştır. Yapılan yorumların \% 41,4 olumsuz, \%30,5'inin tarafsız, \%22,2'sinin olumlu ve \%5,9'da konudan bağımsız farklı bir durumla ilişkili yorum olduğu tespit edilmiştir.

Özgünlük: Gelişen teknolojiler ve küreselleşme markaların tüketici iletişiminde geleneksel iletişim kanallarının yanında yeni iletişim kanallarını da etkin bir şekilde kullanmasını sağlamıştır. Tüketici iletişiminde kullanılan yeni iletişim kanallarının başında sosyal medya uygulamaları gelmektedir. Özellikle markalar pazarlama faaliyetlerinde sosyal medyayı etkin şekilde kullanıp, tüketicilerin isteklerini dikkate alarak marka imajlarını ve tüketicilerin markalarına karşı tutumlarını şekillendirmektedir. Benzer şekilde sosyal medya kullanımı ile birlikte tüketiciler sürekli iletişim halinde oldukları markalar ile yaşadıkları olumlu ve olumsuz deneyimleri de sosyal medya kanalları aracılığıyla paylaşmaktadır. Olumlu paylaşımlar işletme itibarında ve imajında pozitif etki yaratırken, olumsuz paylaşımlar ise işletme imaj ve itibarını negatif yönlü etkilemektedir. Tüketicilerin sosyal medyada marka hakkında çeşitli söylemlerde bulunması noktasında işletmeler açısından önemli olan tüketicilerin söylediklerini iyi analiz etmektir. Bu bağlamda konunun nasıl ve ne gibi sorularla derinlemesine incelenmesi ve tüketici söylemlerinin de derinlemesine analizinin yapılması çalışmayı özgün kılmaktadır. Çalışma sonuçlarının markalara yol gösterici olacağı düşünülmektedir.

Anahtar Kelimeler: Marka, Ağızdan Ağıza İletişim, Elektronik Ağızdan Ağıza İletişim, Pegasus

JEL Sınıflandırması: M31, M39 


\title{
EFFECTS OF NEGATIVE EXPERIENCES ON BRANDS ON THE ELECTRONIC WORD OF MOUTH (E-WOM): PEGASUS EXAMPLE
}

\begin{abstract}
Purpose: The aim of this study is to determine how negative situations experienced by brands affect electronic word of mouth (eWOM).

Method: Qualitative research design is preferred in this study. The comments made on the apology message shared by Pegasus airlines as a result of the plane crash was analyzed by using the case study method. One of the most widely used social networking site in Turkey has preferred to work with İnstagram and 1351 user comments analyzed.
\end{abstract}

Findings: As a result of the analysis, 42 themes were gathered under 10 categories. It was determined that the comments made were $\% 41,4$ negative, $\% 30,5$ neutral, $\% 22,2$ positive and $\% 5,9$ related to a different situation independent of the subject.

Originality: Developing technologies and globalization enabled brands to use new communication channels effectively in addition to traditional communication channels in consumer communication. Social media applications are at the forefront of new communication channels used in communication with the consumer. Especially, brands shape their brand images and attitudes of consumers towards their brands by taking into consideration the wishes of consumers by using social media effectively in their marketing activities. Similarly, with the use of social media, consumers share the positive and negative situations they experience with the brands they are in contact with through social media channels. While positive shares have a positive effect on business reputation and image, negative shares affect business image and reputation negatively. It is important to analyze what consumers say, which is important for businesses, in terms of making various discourses about the brand on social media. In this context, the in-depth examination of how and with what kind of questions and analysis of consumer statements makes the study unique. The results of the work are considered to be a guide for brands.

Keywords: Brand, Word Of Mouth, Electronic Word-Of-Mouth, Pegasus

JEL Classification: M31, M39 


\section{GİRİŞ}

Küreselleşme ve gelişen iletişim teknolojileri birçok alanda olduğu gibi pazarlama alanında ve pazarlamanın faaliyetlerini sürdürmesindeki temel unsur olan tüketicilerin davranışları ve alışkanlıkları üzerinde de son derece etkili hale gelmiştir. Değişen yaşam tarzları ve alışkanlıklar, tüketicilerin zamanının büyük bölümünü internetteki sosyal medya platformlarında geçirmelerine neden olmuştur. Bu durum günümüzdeki pazarlama faaliyetlerinin de bu platformlarda artık daha aktif olduğunun bir göstergesidir. Tüketicilerin birbirleri ve markalarla olan iletişimleri bu sosyal medya araçları üzerinden gerçekleşmektedir. Sosyal medya üzerinden tüketiciler arasında sağlanan bu iletişim şekli ağızdan ağıza iletişimin sanal mecraya taşınmasına neden olmuştur. $\mathrm{Bu}$ durum da elektronik ağızdan ağıza iletişim kavramının ortaya çıkmasına neden olmuştur.

Negatif ağızdan ağıza iletişimin, pozitif’e göre daha hızlı yayıldığı kabul edilmektedir. Bu bağlamda olumsuz iletişim özellikle tatmin sağlayan markaların ürünlerinin yok olmasına neden olabilmektedir. $\mathrm{Bu}$ durum ağızdan ağıza iletişiminin gücünü göstermektedir (Helm, 2000:158-161). İnternetin sağladığ1 avantajlar (hız, zaman ve mekandan bağımsız olması) ağızdan ağıza iletişimi kolaylaştırmıştır (Nicholls, 2003; Stateman, 2005: 27). Dye'ye (2000) göre ABD'deki tüm mal ve hizmetlerin \% 67'sinin ağızdan ağıza iletişimden etkilendiği tahmin edilmektedir (Dobele, Toleman ve Beverland, 2005: 143-145).

Her marka zaman zaman olumsuz durumlarla karşı karşıya kalabilmektedir. Geleneksel pazarlama iletişiminde olumsuz bir durumla karşı karşıya kalan markalar buna ilişkin kamuoyu açıklamalarını gazeteler, TV kanalları ve radyolar aracılı̆̆ıyla yaparken, günümüzde markaların kullandıkları sosyal medya hesapları bu noktada önemli bir iletişim aracı olarak karşımıza çıkmaktadır. Geleneksel pazarlama iletişiminde tüketiciden anında geri bildirim alınması mümkün değilken, günümüzdeki pazarlama iletişiminde tüketicilerden geri bildirimler anında gelmektedir. Aynı zamanda günümüz tüketicileri de markaların sosyal medya kullanmalarına olumlu yaklaşmakta ve aynı zamanda sosyal medya kullanımı da tüketici davranışlarına olumlu etki etmektedir.

Çevrimiçi paylaşım kanallarını ve çeşitli etkinliklere katılmayı içeren sosyal medya, markaların cazip hedef kitlelerle iletişim kurması için giderek daha önemli bir mecra haline gelmiştir (Murdough, 2009). Sosyal medya işletmelerin itibarlarını ve imajlarını yönetmede önemli bir araçtır. Sosyal medyada bilgiler anında yayılmaktadır. Bu bağlamda markalar haklarında söylenenleri, yazılanları ve konuşulanları iyi analiz etmeli ve kullanıcıların söylediklerine kulak vermelidir. Çünkü bu noktada tüketici söylemleri uzun vadede marka itibarında ve imajında etkili olmaktadır. Özellikle sosyal medyada tüketiciler bir marka hakkında diğer kullanıcıların ve ilgili markanın yarattığı içerikleri gözlemlediğinde oluşan marka imajından etkilenebilmekte ve ardından satın almayı tercih etmektedirler. Markalar özellikle yaşanan kriz durumlarında tüketici ile olan bu iletişim sürecini iyi yönetirse olumlu imajlarını sürdürmekte ve hatta itibarlarını da arttırmaktadırlar. 
$\mathrm{Bu}$ doğrultuda bu çalışmanın amacı markaların yaşadıkları olumsuz durumların elektronik ağızdan ağıza iletişimi nasıl etkilediğini belirlemektir. Bu amaçla aşağıda yer alan araştırma sorularına cevap aranmıştır:

- $\quad$ Markaların yaşadığı olumsuz durumlarda e-wom'da öne çıkan temel konular nelerdir?

- Markanın yaşadığı olumsuz durumlarda e-wom olumlu olmakta mıdır?

- Markaların yaşadığı olumsuz durumların e-wom'a yansımaları nasıldır?

- Markaların yaşadığı olumsuz durumlarda tüketiciler markayı desteklemekte midir?

Konuya ilişkin yapılmış benzer çalışmalara literatürde rastlanmamıştır. Ayrıca konunun nasıl ve ne gibi sorularla derinlemesine incelenmesi çalışmayı özgün kılmaktadır.

\section{KAVRAMSAL ÇERÇEVE}

\section{Sosyal Medya}

Kaplan ve Haenlein (2010: 61), sosyal medyay1 “web 2.0'ın ideolojik ve teknolojik temelleri üzerine inşa edilmiş ve kullanıcı tarafindan oluşturulan içeriğin oluşturulmasına ve değişstirilmesine izin veren bir grup internet tabanlı uygulama" olarak tanımlamıştır.

Literatürde yer alan sosyal medya tanımları incelendiğinde ise bu tanımların ortak özellikleri şu şekilde sıralanmıştır (Güçdemir, 2017: 15):

- Kullanıcılar sosyal medya içeriğini (haber, fotoğraf ve video gibi) oluşturmakta ve bunları sanal topluluklarla paylaşmaktadır.

- Her kullanıcı kendi içeriğini oluşturmaktadır.

- Katılım online ortamlardan yapılmaktadır.

- $\quad$ Sosyal içerikli web siteleridir.

Bu bağlamda sosyal medya araçlarının bireylere kişisel düşünce ve duygularını paylaşma imkanı sağlamanın yanında, farklı katılımcılarla da online ortamda bir araya gelme ve etkileşim sağlayarak sosyalleşme imkanı sunduğunu da söyleyebilinir.

Tüketicilerle etkileşim ortamı oluşturan sosyal medya, işletmelerin var olan tüketicilerini korumalarını ve yeni tüketiciler kazanmalarını sağlayarak, marka farkındalığı, satış artışı ve marka imajı oluşturmanın yanında müşteri hizmetlerinin iyileşmesine de katkı sağlar. Ayrıca işletmelerin tanıtım kampanyaları ve tutundurma faaliyetleri içinde görece daha ucuz bir platform olarak karşımıza çıkmaktadır (Bajpai, Pandey ve Shriwas, 2012)

Sosyal medya, müşteri ilişkileri yönetimi, müşteri hizmetleri, tüketici araştırması, olası satış yaratma, satış promosyonu, dağıtım kanalı, ücretli pazarlama, reklam kanalı ve marka bilinci oluşturma gibi birçok pazarlama etkinliği için bir kanal görevi görebilmektedir (Schmitt, 2012).

Tüketici ile oluşturulan bu temas noktalarından aktarılan düşünceler, duygular, algılar, görüntüler ve deneyimler tüketici belleğinde markaya ilişkin bir dizi ilişki kurmaktadır (Keller, 2009). 


\section{Sosyal Medya Aracı Olarak İnstagram}

Değişen ve dijitalleşen yeni pazarlama iletişiminde işletmeler ile tüketicilerin birbirine ulaşabildiği en kolay, en hızlı ve en düşük maliyetli yol sosyal medya uygulamalarıdır.

Özellikle son yıllarda oldukça popüler olan sosyal ağların sosyalleşmek ve eğlenmek dışında farklı kullanım amaçları da mevcuttur (Trusow, Bucklin ve Pauwels, 2009: 92). Sosyal medya kullanıcıları bilgilenmek, farklı içeriklerden faydalanmak, pazarlama ve reklam amaçlı sosyal ağları kullanmaktadırlar. İşbirliği sağlama, kişiye özgünleştirebilme özelliği ve kullanıcı esaslı içerik paylaşabilme gibi özellikleriyle sosyal ağların çekiciliği artmaktadır (Tonta, 2009: 742). Sosyal ağlar artık gündelik hayatımızın önemli bir parçası olmakla birlikte ve faaliyetlerimizin önemli bir kısmını da buralardan yönetme şansına sahibiz.

Sosyal medyanın oluşması bir takım sosyal medya araçları ile olmaktadır. Bu sosyal medya araçlarının neredeyse tamamında bireyler bu araçları kullanan kişilere paylaşım yapabilmektedir. Sosyal medya araçlarının var olduğu ortamlar; ortaya çıkış sebepleri, teknik özellikleri, sağladığı imkânlar, kullandıkları uygulamalar ve paylaşılan içeriklere göre farklılaşmıştır. Sosyal medya araçlarının sınıflandırılmasına ilişkin literatürde farklı yaklaşımlar yer almaktadır (Mangold ve Faulds, 2009; Weinberg, 2009; Akar, 2010; Kaplan ve Haenlein, 2010; Safko, 2010; Zarella, 2010).

Farklı yazarların sınıflandırmaları içerisinde yer alan sosyal ağlar, sosyal medya siteleri ve medya paylaşım siteleri kategorisi altında Facebook, Myspace, Twitter, Snapchat ve İnstagram gibi platformlar yer almaktadır.

Sosyal medya araçlarından biri olan İnstagram özellikle ülkemizde geniş bir kullanıcı kitlesine sahiptir. Ocak 2020'de Türkiye'de internet kullanıcısı 62,07 milyon iken sosyal medya kullanıcısı ise 54,00 milyondur. Kullanıcıların en fazla tercih ettiği sosyal medya uygulamalarında ise İnstagram Youtube'nin hemen ardından \%83'lük bir oran ile 2. sırada yer almaktadır (Kemp, 2020).

İnstagram, 2010 yılında Kevin Systrom ve Mike Krieger tarafından kurulmuş olup fotoğraf ve video paylaşım platformu olarak tasarlanmıştır. Hızla artan kullanıcı sayısı nedeniyle 2012 yılında 1 milyon dolara Facebook'a satılmıştır (Kırcova ve Enginkaya, 2015: 61). İnstagram'ı diğer sosyal medya platformlarından ayıran özellik görsel ağırlıklı olmasıdır. Bu platformda kullanıcılar fotoğraf ve videolarını biçimlendirerek filtlereyerek takipçileri ile paylaşabilmektedirler. Paylaşımlar takipçilere yorum ve beğeni yapma imkanı sunmaktadır. Bunun yanı sıra "İnstagram Stories” özelliği ile 24 saat sonra silinecek fotoğraf ve videolar paylaşlabilmekte ve storyler üzerinden anket yapılabilmektedir. Kullanıcıların birbirleri ile mesaj yoluyla iletişim kurmasına imkan veren DM (Direct Message) özelliği bulunan İnstagram'da kullanıcılar gerçek zamanlı olarak takipçileri ile iletişim kurabileceği canlı yayın özelliğine sahiptir.

Etkileşim bağlamında İnstagram'ın en önemli faydası ise bireylerin etkileşimini sağlayan bir platform sunmasıdır. İnstagram kullanıcıları kendi aralarında olduğu kadar, farklı markalar veya markaların 
elçilerinin paylaşımlarına yorum yaparak, etiketleyerek ya da doğrudan mesaj göndererek iletişim kurma imkanına sahiptirler. Bunun yanı sıra etiketler kişi o markayı takip etmese bile o markanın gönderilerini görüntüleyebilmesi firsatını sunmaktadır; bu sayede kullanıcı da o markayla etkileşim kurabilmektedir. Ayrıca, İnstagram tüm tüketicilerin birbirileri ile markaya ilişkin konuşmalar yaparak veya tavsiyede bulunarak markayı değerlendirmelerine de firsat sunmaktadır (Bowen, 2015: 202). Bu bağlamda İnstagramın görsel özelliklerine ek olarak etkileşimli yapıya sahip olması, hem tüketiciler hem de markalar için pazarlama iletişimininde İnstagramın etkin bir kanal olmasını sağlamaktadır.

\section{Sosyal Medyada Pazarlama İletişimi}

Son yıllarda önemli ölçüde ilgi gören sosyal medya pazarlaması çalışmaları; markalı sosyal medya içeriği (Ashley ve Tuten, 2015), müşteri katılımı (Dessart, Veloutsou ve Morgan-Thomas, 2016), çevrimiçi marka toplulukları (Brodie, Ilic, Juric ve Hollebeek, 2013), sosyal medyanın pazarlama karmasındaki rolü (Srinivasan, Rutz ve Pauwels, 2016) ve sosyal medyanın firma performansı üzerindeki etkisi (Srinivasan vd., 2016; De Vries, Gensler ve Leeflang, 2017) ile ilişkili konuları aydınlatmıştır.

Sosyal medya platformları bir takım kullanıcı fonksiyonelliğini kolaylaştırmıştır. Bu fonksiyonlar; kimliği açığa vurma, karşılıklı konuşmalar, paylaşımlar, mevcudiyet (kullanıcıların diğer kullanıcıların varlığının farkında olma derecesi), ilişkiler, itibar yönetimi ve gruplar (kullanıcıların topluluk oluşturabilme derecesi) olarak yedi ana kategoride tartışılmıştır (Kietzmann, Hermkens, McCarthy ve Silvestre, 2011).

Önerilen sosyal medya işlevlerinin ana pazarlama sonuçları arasında; pazarlamacıların kullanıcının kendi kendini tanıtması için araçları kolaylaştırmaları, çevrimiçi sohbetleri izlemeleri ve etkilemeleri, içerik yönetim sistemleri geliştirmeleri ve müşterilerle gerçek zamanlı ve samimi etkileşimleri kolaylaştırmaları yer almaktadır (Tafesse ve Wien, 2018).

Hanna, Rohm ve Crittenden (2011), geniş bir sosyal ağ ile sonuçlanan bağlantılar oluşturmada sosyal medyanın gücünü vurgulamışlardır ve bu geniş ağında, tüketicilerin 'medya sürecine aktif katılımcılar' olmalarını sağlayan bir medya ortamı yarattığını dile getirmişlerdir. Sonuç olarak, pazarlama artık yalnızca erişim yoluyla dikkat çekmekle ilgili değildir; bunun yerine, etkileşim ve katılım yoluyla dikkat çekip bunu sürdürmeye odaklanmalıdır. Müşteri etkileşimi ve katılımına olan bu odaklanmanın çoklu platformları kesintisiz bir sosyal medya deneyimine entegre eden bütüncül bir sosyal medya stratejisine duyulan ihtiyaç da dahil olmak üzere sosyal medya uygulaması için önemli etkileri vardır (Hanna vd., 2011; Tafesse, 2016).

Günümüz markaları bütünleşik pazarlama iletişimi dediğimiz bir iletişim yaklaşımıyla hareket etmekte ve tek bir iletişim aracı yerine birden fazla iletişim aracını kullanarak tüketicilere ulaşmaktadırlar. Özellikle farklı tüketici gruplarının yer aldığı sosyal medya platformları markaların 
tüketicilere ulaşmasında en etkin, en hızlı ve en düşük maliyetli iletişim aracıdır. Markalar farklı sosyal medya platformlarında eş anlı olarak gönderilerini yayınlayarak tüketicilere ulaşmakta ve tüketicilerden hızlıca geri dönüş alabilmektedir. Benzer şekilde günümüz tüketicileri de markalara ulaşmada en çok sosyal medya platformlarını kullanmakta ve görüşlerini, önerilerini, şikayetlerini ve yaşadığı sorunları bu platformlar üzerinden aktarmaktadır.

$\mathrm{Bu}$ bağlamda tüketicilerin ne söylediği markalar açısından önem arz etmektedir. $\mathrm{Bu}$ noktada markaların görevi A'dan Z'ye tüm tüketicileri dinlemek, anlamak, yanıtlamak ve özellikle de onların söylemlerini iyi analiz ederek bu analizler doğrultusunda aksiyon planları geliştirmektir.

Yalnızca tüketiciler bağlamında değil markalar açısından baktığımızda da sosyal medya itibar ve imaj yönetiminde önemli bir araçtır. Bilgilerin oldukça hızlı yayıldığı sosyal medyada markalar kendilerine ilişkin yazılanları, söylenenleri ve konuşulanları takip etmeli; itibarlarını etkileyecek ve imajlarını zedeleyecek bilgileri analiz ederek, olumsuz söylemleri inceleyerek bu söylemlerle başa çıkmak için davranış şekli belirlemelidir (Güçdemir, 2017).

Sonuç olarak işletmelerin sosyal medyanın bilgi açısından zengin ortamından yararlanmak ve değer yaratmak için müşteri katılımı ve veri analizi gibi yeni organizasyon becerileri edinmeleri gerekmektedir (Choudhury ve Harrigan, 2014; Harrigan, Soutar, Choudhury ve Lowe, 2015; Stephen ve Brat, 2015). Bu beceriler ve analizler işletmelerin stratejik pazarlama hedeflerini gerçekleştirirken yol gösterici olacaktır.

\section{Elektronik Ăğıdan Ăğıza İletişim (E-wom)}

Geleneksel anlamda ağızdan ağıza iletişim tüketicilerin daha önce deneyimlediği belli bir ürün, marka veya hizmete yönelik olarak edindiği tecrübe, bilgi ve fikirlerini diğer tüketicilerle paylaşım sürecidir (Hawkins, Best ve Coney, 2004).

Gelişen teknolojiler, internet kullanımının artması, sosyal ağların oluşması ile birlikte ağızdan ağıza iletişim kavramı çevrimiçi platformlara taşınmıştır. Tüketiciler bilgi ve deneyimlerini forumlar, bloglar, yorum siteleri, sosyal ağlar, haber grupları gibi web tabanlı uygulamalar üzerinden paylaşmaya başlamışlardır. Bu noktada ortaya elektronik ağızdan ağıza iletişim kavramı çıkmıştır.

Hennig-Thurau, Gwinner, Walsh ve Gremler (2004)'a göre elektronik ă̆ızdan ăğza iletişim, çevrimiçi (online) eski, mevcut veya potansiyel müssterilerin, ürünler ve işletmeler hakkında internet aracılı̆̆ılla bilgi, deneyim ve fikirlerini pozitif veya negatif yönde paylaşmalarıdır.

Sosyal medya tarafından kolaylaştırılan üç ana bilgi akışı vardır. Bunlardan ilki işletmeden tüketiciye bilgi akışını sağlayan marka gönderileri ve sosyal medya reklamlarıdır (Hewett, Rand, Rust ve Heerde, 2016). İkincisi tüketiciden işletmeye bilgi akışını kolaylaştıran sosyal medya, yorumlar, tepkiler, düşünceler ve kullanıcı tarafından oluşturulan içeriklerdir (Gensler, Volckner, LiuThompkins ve Wiertz 2013). Üçüncüsü ise, tüketicilerin birbirleri ile etkileşimini kolaylaştıran ewom veya marka toplulukları biçiminde karşımıza çıkmaktadır (Dessart vd., 2016). 
Elektronik ağızdan ağıza iletişim sonucunda oluşan bilgi, bilgiyi oluşturan kişi veya ilgili platform tarafından silinmediği müddetçe, zamandan ve mekandan bağımsız olarak internete erişebilen tüm kullanıcılar tarafından ulaşılabilir durumdadır (Amblee ve Bui, 2008; Cheung ve Lee, 2012).

Tüketiciler direkt satın alma yapmasalar bile sosyal medya aracılığıyla çok kolay bir şekilde markayı ve markanın tüketicilerle iletişimini izleme şansına sahiptirler. Mevcut tüketicilerin markaya yönelik olumlu ya da olumsuz eleştirileri diğer tüketicilerde bir algı oluşturmakta ve onların da gelecekteki satın alma kararlarında etkili olmaktadır. Bu bağlamda markaların kitleleriyle etkileşimde bulunması sürdürülebilirlikleri açısından önem arz etmektedir (Ganesh, 2018).

Milyonlarca tüketicinin birbirleriyle son derece hızlı ve oldukça kolay bir şekilde iletişim kurmalarını sağlayan sosyal medya, tüketicilerin etkinliği ve etkililiğini arttırmıştır. Bu durum da tüketicilerin güçlenmesini sağlamıştır. İşletmeler sosyal medya faaliyetlerinde merkez olarak kendi web sayfalarını kullanabilmekte veya sosyal medya üzerinden de tüketicilere ulaşabilmektedir (Mangold ve Faulds, 2009).

E-wom işletmenin bazı konularında önemli bir etkiye sahiptir. Bu konular; pazar araştırması, hizmet kalitesinin daha iyi hale getirilmesi, işletme itibarının inşası ve güçlendirilmesi, çalışan performansının değerlendirilmesi, iş performansı, şikayet yönetimi gibi konulardır (Hsu, 2012; Yacouel ve Fleischer, 2012; Browning, So ve Sparks, 2013; Levy, Duan ve Boo, 2013; Mauri ve Minazzi, 2013; Nieto, Hernández-Maestro ve Muñoz-Gallego, 2014; Inversini ve Masiero, 2014; Xie, Zhang ve Zhang, 2014).

Sundaram vd., (1998) ağızdan ağıza iletişime katılım anlamında pozitif veya negatif temelli katılım motivasyonlarını 8 kategoride toplamıştır. Bunlar; işletmeye yardım, işletmeden intikam alma, tavsiye arayışı, endişe azaltma, akıllı müşteri olarak öz değer edinme, ürüne dahil olma, negatif ve pozitif yönlü tavsiyede bulunmadır. Bu ayrımlarda sohbet sosyal medyada gerçekleştiğinde ise; bilgilerin oluşturulduğu, paylaşıldığı, değiştirildiği ve ortadan kaldırıldığı temeli işbirliğine dayanan bir süreç ortaya çıkmaktadır. İşbirliğine dayalı bu süreç tabanında mevcut pazar, işletmelerin, müşterilerin, tüketici topluluklarının ve firma ağlarının yer aldığı, diyalogların gerçekleştiği bir forum haline gelirken işletmelerin, tüketici ile işbirlikçi olma mecburiyeti ise dönüşümün başlangıç noktası olmaktadir (Evans, 2008).

Tüketicilerden hizmet tatminsizliği fazla olanlar daha fazla ağızdan ağıza iletişim gerçekleştirmektedirler. Tüketiciler satın aldıkları bir ürün veya hizmetten memnun olmazlarsa şikayet etmek, farklı markalara yönelmek veya olumsuz ağızdan ağıza iletişimle markaya ilişkin olumsuz düşüncelerini çevreye aktararak tepki verirler (Zeelenberg ve Pieters, 1999: 89). Smith ve Vogt (1995) olumsuz marka imajının en önemli nedenlerinden birinin ağızdan ağıza iletişsim olduğunu ve bunun yanında tüketicilerin de memnuniyetsizliklerini markaya iletmek yerine çevresine anlatmayı tercih ettiklerini belirtmişlerdir. 
Özellikle elektronik ağızdan ağıza iletişimin olumsuz olması, işletmelerin itibarına ve marka imajına zarar verirken; olumlu elektronik ağızdan ağıza iletişim ise markaların pazarlama çabalarını desteklemektedir (Kutlu ve Ayyıldı, 2017: 44).

Buradan hareketle çevrimiçi müşteri yorumlarının iki önemli görevinden ilki bilgi sağlayıcı olması, ikincisi ise tavsiye sunucu olmasıdır. Bu yorumlar, turizm sektörü başta olmak üzere birçok sektörde ürünlerin deneyimlenmesi veya hizmetlere ilişkin pozitif veya negatif yönlendiriciler olarak önem arz etmektedir. Bunun yanı sira bu yorumlar potansiyel tüketicileri etkilemekte, algılanan riskleri azaltmakta ve belirsizlikleri ortadan kaldıran dış bilgi kaynaklarını oluşturmaktadır (Klein, 1998; Morgan, Pritchard ve Piggott, 2003; Pan, MacLaurin ve Crotts, 2007; Park, Lee ve Han, 2007; Laboy ve Torchio, 2007; Zhang, Craciun ve Shin, 2010).

\section{YÖNTEM VE ANALIZ}

\section{Araştırma Yöntemi}

$\mathrm{Bu}$ çalışmada nitel araştırma deseni tercih edilmiş olup örnek olay yönteminden faydalanılmıştır. Örnek olay; araştırmacının sınırlandırılmış tek veya daha çok durumu belli bir süreçte türlü veri elde etme araçları (gözlemler, görüşmeler, dokümanlar gibi) ile derinlemesine incelediği, durumların ve duruma bağlı temaların ortaya çıkarıldığı nitel bir araştırma yaklaşımıdır (Gürbüz ve Şahin, 2018).

Yazılı veya görsel araç gereçlerin sistematik olarak taranması ve belli kategoriler altında toplanarak tematik olarak analiz edilmesi süreci olan içerik analizi bilhassa medyadaki bildirilerin yapısının ve içeriğinin değerlendirilmesini sağlamaktadır (Rubin, Rubin ve Piele, 2005). Bu nedenlerden dolayı araştırmanın bu yöntemle yapılmasına karar verilmiştir. $\mathrm{Bu}$ bağlamda çalışmamızda yazılı dökümanlardan faydalanılmış ve nitel veri analiz yöntemlerinden biri olan içerik analizi ile elde edilen verilerin analizi gerçekleştirilmiştir.

İçerik analizinde önemli noktalardan biri yapılan kodlamaların güvenirliliğinin sağlanmasıdır. Kodlama güvenirliliğinin sağlanmasında veri setinde yer alan kodlama benzerlikleri sayısal olarak karşılaştırılmalı ve kodlama yüzdesinde de 70 ve üstü değere ulaşılmalıdır (Yıldırım ve Şimşek 2018; Yüksel ve Yüksel, 2004). Çalışmada yalnızca bir araştırmacı rol aldığı için bireysel güvenirliğin elde edilmesinde, başka bir akademisyenden yardım alınarak kodlamaların yeniden temalaştırılması istenmiştir. Temalaştırma sonucunda kategorilerin uyumlu çıkmasından dolayı bireysel güvenirliliğin sağlandığı varsayılmıştır.

İçerik analizinde veriler dört aşamada; verilerin kodlanması, temaların bulunması, kategorilerin oluşturulması ve bulguların yorumlanması şeklinde sırasıyla analiz edilmektedir (Yıldırım ve Şimşek, 2018:243-252).

$\mathrm{Bu}$ çalışmada da işletmelerin yaşadığı olumsuz durumların e-wom'u nasıl etkilediğini incelemek amaciyla örnek olay modeli çerçevesinde 05.02.2020 Çarşamba günü saat 18:19' da Pegasus Havayolları'na ait İzmir-İstanbul seferi yapan PC2193 sefer sayılı Boeing 737 tipi uçağın Sabiha 
Gökçen havalimanında yaptığı kaza sonucunda markanın İnstagramda da yayınladığı özür metnine yapılan tüketici yorumları analiz edilecektir.

\section{Verilerin Analizi ve Kodlama}

BBC'nin haberine göre; “Pegasus Havayolları'na ait İzmir-İstanbul seferi yapan PC2193 sefer sayılı Boeing 737 tipi uçak 05.02.2020 Çarşamba günü saat 18:19'da Sabiha Gökçen Havalimanı'na sert iniş yaptıktan sonra duramayarak yaklaşık 50 metre sürüklenip pistten çıkan uçak, 30 metre yükseklikten TEM otoyolu kenarındaki alana düşı̈. Kokpitin de bulunduğu ön taraf ve kuyruk kısımlarının ana gövdeden ayrılarak parçalandı. Uçaktaki yolcular ve mürettebatın bir kısmı, uçaktan kendi imkanlarıyla çıktı. Uçakta 12ülkeden 22 yabancı uyruklu yolcu bulunmakla birlikte Kaza sonucunda yaralı yolcu sayısı 180 iken 3 yolcu da hayatını kaybetmiştir" (BBC, 2020).

Kazanın ardından 06.02.2020 tarihinde pegasus havayolları İnstagram sayfasında siyah zemin üzerine beyaz harflerle "DUYURU" yazan bir gönderi yayınlayarak açıklama olarak "İzmir Adnan Menderes-Sabiha Gökçen seferini yapan PC2193 sefer sayılı TC-IZK kuyruk tescilli uçağımızın 5 Şubat 2020'de yaşadığı kaza sonrasında resmi kaynakların da teyit ettiği üzere 3 misafirimizin hayatını kaybettiğini üzülerek bildiririz. Acımı çok büyük. Kazada hayatını kaybeden misafirlerimize Allah 'tan rahmet, aile ve yakınlarına baş sağlı̆̆ diliyor, yakınlarının acılarını yürekten paylaşıyoruz. Yaralı olan yolcularımızın tedavileri hastanelerde devam etmektedir. Tüm yaralı yolcularımıza acil şifalar diliyoruz. Şu anda önceliğimiz vefat eden misafirlerimizin yakınlarına destek olup yanında bulunmak, acılarına ortak olmak ve yaralı yolcularımızın hastanelerdeki tüm ihtiyaçlarını karşılamaktır.” Metinini İngilizce ve Türkçe olarak yayınlamıştır.

Çalışmanın alanizi için markanın İnstagram sayfasında yer alan bu gönderiye yapılan kullanıcı yorumları 17.02.2020 tarihinde elde edilmiştir. Verilerin elde edildiği bu tarihe kadarki tüketicilerin içeriğe katılım durumuna baktığımızda toplam beğeni sayısı 10.226, yorum sayısı 2.357dir. Yorumlardaki hashtag kullanımına bakıldığında ise toplamda 38 yorum olduğu tespit edilmiştir.

Çalışma kapsamında yapılan bu içerik analizinde Türkçe dışındaki dillerde (İngilizce, Fransızca, Almanca ve Rusça) yapılan diğer yorumlar da çevirileri yapılarak değerlendirilmeye alınmıştır. Analizde yer alan farklı dillerdeki yorumlar yabancı kullanıcı yorumu şeklinde kodlanmış ve toplamda 23 adet yabancı yorum olduğu tespit edilmiştir. Araştırmada yapılan yorumlar tarih olarak ilkten sona doğru bir sıra akışı içinde taramaya ve analize tabi tutulmuştur.

Yapılan analizde olarak söz konusu gönderiye yapılan 2.357 yorumdan kullanıcıların birbirlerine verdikleri cevaplar elenerek doğrudan gönderiye yönelik yapılan ilk yorumlar seçilmiştir. Bu seçimle beraber yorum sayısı 1483 olarak tespit edilmiştir ancak yorumlarda yalnızca emoji kullanan tüketiciler olduğu tespit edilmiş ve bunlar emoji ile yapılan yorum şeklinde kodlanmıştır. Kodlama sonucunda yalnızca emoji kullanan tüketici sayısı 132 olarak hesaplanmıştır. Kelime veya cümle içermeyen bu 132 yorum kodlamaya dahil edilmemiştir. Veri seti okunarak bir tarama ve seçim kriteri 
belirlenmiş, ardından verilerin tamamı yeniden taranmış ve belirlenen tarama ve seçim kriterlerine göre toplamda 1351 tüketici yorumu kodlanmıştır. Kodlamanın ilk aşamasında birbiri ile ilişkili olan veriler belirli temalar altında birleştirilmiştir. Ardından bu temalar araştırma soruları bağlamında ilişkisel açıdan ele alınmış ve böylece kategoriler oluşturulmuştur.

\section{Bulgular}

Çalışmada ilk olarak kullanıcı yorumlarının tamamı baştan sona okunmuş ve yorumların 4 temel başlık altında toplanmasına karar verilmiştir. Veriler olumsuz kullanıcı yorumu, tarafsız yorum, destekleyici kullanıcı yorumu ve farklı bir duruma ilişkin yorum şeklinde 4 temel başlık esas alınarak analiz edilmiştir. Bu bağlamda bu yorumlara ilişkin frekans ve yüzde değerleri aşağıdaki tabloda yer almaktadır.

Tablo 1. Yorum Türü Bazında Yüzde Ve Frekans Değerleri

\begin{tabular}{l|c|c}
\hline Yorumların sınıflandırması & $\mathbf{f}$ & $\mathbf{\%}$ \\
\hline Olumsuz Kullanıcı Yorumu & 561 & 41,4 \\
\hline Tarafsız Yorum & 413 & 30,5 \\
\hline Destekleyici Kullanıcı Yorumu & 297 & 22,2 \\
\hline Farklı Bir Duruma İlişkin Yorum & 80 & 5,9 \\
\hline Toplam & $\mathbf{1 3 5 1}$ & $\mathbf{1 0 0}$ \\
\hline
\end{tabular}

Tablo incelendiğinde 561 kişi ile en fazla olumsuz kullanıcı yorumunun olduğu görülmektedir. Olumsuz kullanıcı yorumu başlı̆g 1 belirlenirken tüketicilerin kazaya, işletmeye ve gönderiye yönelik yıkıcı eleştirileri dikkate alınmıştır. Bu kategoride tüketiciler; uçuşa, çalışan personele, işletme yönetimine, işletme politikalarına ve markaya yönelik olumsuz yorumlarda bulunmaktadır. Bu yorumlardan bazıları; "Kar hırsı güvenliğin önüne geçerse böyle olur. 2 yılda 3. kaza, demek ki mesaj alinmamiş. Tabi ki hayatini kaybedenleri Allah rahmet etsin, bunun vebalini kim ödeyecek?” “ Bence acilen uçakla birlikte adınızı sildirin yada kendinize iyibi format atın sürekli pegasusta bu vakalar var" "En berbat hava yolu şirketi olduğunuzu söyleyebilirim su bile ücretli rezil bir hava yolu hele birde pilotlarınızın inişi var o yüzden tercih etmiyorum sizi gerekirse binmiyorum.", "Şirketin tüm uçuşları durdurulsun "ş̧eklindedir. Olumsuz yorumlarda tüketiciler en çok "berbatsınız", "rezilsiniz" “güvenilmezsiniz” ve "kötüsünüz” şeklinde kelimeler kullanmışlardır.

Tabloda tarafsız kullanıcı yorumu kategorisi 413 kişi ile 2. sırada yer almaktadır. Tarafsız kullanıcı yorumu kategorisi belirlenirken tüketicilerin yalnızca baş sağlığ 1 ve geçmiş olsun dilekleri dikkate alınmıştır. Buradan hareketle veriler tekrar incelendiğinde 383 kullanıcının "geçmiş olsun" 30 kullanıcınında başı(nız/mız) sağolsun dileklerinde bulunduğu tespit edilmiştir. Bu kategoride tüketiciler yorum olarak yalnızca baş sağlığı dilemiş ya da "geçmiş olsun" yazmışlardır.

297 kişi ile 3. Sırada yer alan destekleyici kullanıcı yorumlarında tüketiciler; “@pegasusairlines siz bizlere ülkece lazımsınız size her zaman sahip çıkacă̆ız”, "Kaptanlar da insan onlar da hata yapar..Illa bir kurban aramamak lazım." "Pegasustan ben çok memnundum. Nazar değdi. Çok 
üzgünüm. Ama yine tercihim pegasus olacak. Talihsiz bir kaza oldu”. “Türk halkına, uçmayı tattıran ve sevdiren Pegasus ailesine geçmiş olsun diyor ve acılarını paylaşıyorum. İyi ki varsınız, varolacaksınız", "Pegasus havayolları yönetimi saw Odesa uçuşlarının açılmasını dört gözle bekliyoruz $\square \square \square \square$ ' şeklinde yorumlar yapmışlardır. Bu kategori altında tüketiciler havayolunu destekleyip, sahiplenmişlerdir. Kazanın herkesin başına gelebileceğini, talihsizlik olduğunu söyleyerek iyi temennilerde ve yapıcı eleştirilerde bulunmuşlar ve “ iyi ki varsınız” , "siz bize lazımsınız" "herkesi uçuran hava yolu" şeklinde sözlerle de desteklemişlerdir.

Farklı bir duruma ilişkin yorum sayısı 80 ile son sırada yer almaktadır. Bu kategori belirlenirken tüketicilerin mevcut kazadan ve yayınlanan gönderiden bağımsız yorumları esas alınmıştır. $\mathrm{Bu}$ kategori altında tüketiciler "Ülke olarak zor günler Rabbim sen yardım et... Şu anda kayseride lodos var çatılar uçuyo binalar sallanıyor...", "Çağrı merkezinize dün sabahtan beri ulaşamıyorum, 2 numaradan da denedim fakat sonuç aynı. Nasıl iletişim kurabilirim ?”, “14 Şubat akşamı 19:55 uçuşunuza binicem. Kıbrısın saati Türkiyeye göre 1 saat geride. Uçuşunuz Kıbrısın saatine göre mi ayarl yoksa 1 saat geri olarak mı düşünücez yani uçuş 18:55 mi ???@pegasusairlines”, “Genel Mudurunuz çok tatli bir amca", "Ülke ve dünya olarak çok zor bir virajdan geçiyoruz inanilmaz sayılarda ölüm ve yaralı haberleri var Allah her kula dayanma ve sabır gücü versin”, "Huzur içinde yatsınlar, başınız sağolsun. 2020 felaketler yılı oldu ancak bunun sadece bir başlangıç olduğunu düşünüyorum. Belki de bu durumda olmayı hak ediyoruz. Bizi cezalandıran ister Allah/Tanrı ister evren ister doğa olsun ancak bunu hak ediyoruz belki de." şeklinde konudan bağımsız yorumlar yaparak durumu içinde bulunulan yıl veya ülkenin durumu ile ilişkilendirmişler ve bu durum şanssızlık ve kader olduğundan bahsetmişlerdir. Yine bu kategori altında pilotluk mesleğinin önemine vurgu yapan yorumlarda yer almıştır.

Analiz kapsamında yorumlarda diğer kullanıcı yorumlarının eleştirildiği dikkat çekmiş ve bu yorumlar "diğer kullanıcılara eleştiriler” şeklinde kodlanmıştır. Bu şekilde kodlanan yorum sayısı 72'dir. Bu gönderilerde kullanıcılar “Bir kuruma bilip bilmeden bu kadar yüklenmek son derece yanlış mevcut kaza başka firma tarafindan da yapılsaydı verilen tepkilerin aynısı verilir miydi hiç sanmıyorum. Alınan eğitimlerden tutun da, uçağın bakımı, parçaları vs. herkesin bir fikri var..", "Başka uçakta uçsasınız düşseniz ölmicek gibi konuşup yorum yapmıyormusunuz gülüyorum sahiden komik kimsenin canına bilerek kast etmedi sizde bulduğunuz her firsatta bişeyleri karalayın...”, "Peki size bişey söyliyimi babanizin firmasi olsaydi dünyanin en iyi firmasi olarak gorürdünüz yaziklar olsun size koruyup kollamamiz gereken yerde hakaret ediyorsunuz sanki thy nipin hiç uçaği

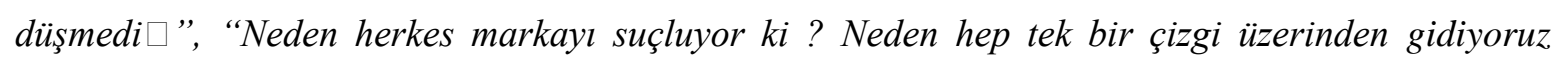
olaylara? Acımız büyük anlyyorum vefat edenlere allahtan rahmet diliyorum olmaması gereken bir kazaydı ama hiç bir olayın tek bir suçlusu yoktur önyargılardan kaçınmak vicdanen en iyisidir marka suçlamak kötüye yormak kimsenin eline bir şey geçirmez....”, “Insanlar ölmüşs!!! Pegasusa aklınızca hesap soruyosunuz ? Pardon şikayet ettiğiniz firma 90 tl uçus verirken o ödemeyi yaparken çok 
meтnипsunuz..." şeklinde yorumlar yapmışlardır. Bu kategorideki yorumların tamamının markayı destekleyici kullanıcı yorumları olduğu tespit edilmiştir.

Çalışmada yapılan kodlamalar tümevarım yöntemi ile gerçekleştirilmiş olup ilk aşamada gerçekleştirilen açık kodlama tablosu örnek olarak verilmiştir.

Tablo 2. Uçağa, Uçuşa ve Uçuş Ekibine Yönelik Yorumlar Kategorisini Oluşturan Açık Kodlama Tablosu

\section{Uçağa, uçuşa ve uçuş ekibine yönelik yorumlar}

Aynı tip uçă̆ın 3. Kazasının olması

Hizmet kalitesinin düşük olması

Hizmet, personel ve pilotlar güzel

Kabin personeelinin senli- benli konuşması

Kabin ekibinin asık yüzlü olması

Kabin ekibinin bazıları fazla ukala ve kendini beğenmiş

Kabin ekibinin çocuk emniyet kemerini dağıtmaması

Kabin ekibinin dil bilmemesi

Kabin ekibinin eğitim eksikliği

Kabin ekibinin ilgisiz olması

Kabin ekibinin kaba uslübü

Kabin ekibinin özensiz tavırları

Kabin ekibinin rahat tavirları

Kabin ekibinin saygısız olması

Kabin ekibinin uçak güvenlik bilgilerini tam anlatmaması

Kabin ekibinin yolculara kötü davranması ve bağırması

Kabin ekibinin yolcuyu aşağılaması -terslemesi

Koltukların sert plastic olması(konforsuz)

Koltukların yırtık olması

Çalışanların yolculara değer vermemesi

Çalışanların yolculara küfür etmesi

Pilot seçimindeki özensizlik

Pilotlar minubus şoförü gibi olması

Pilotların acil durum anonsu yapmaması

Pilotların aşırı cesur olması

Pilotların eğitim sürelerinin kısa olması

Pilotların eğitimsiz olması

Pilotların genç olması

Pilotların ihmalkar davranmas

Pilotların kulenin talimatlarını uygulamaması

Pilotların piste doğru iniş yapmamaları
Pilotların uçuş süreleri ve uçuş sayılarının fazla olmas1

Pilotların uçuşlarının konforsuz olması

Pilotların yanlış kararı

Pilotluk eğitiminin çok kolay olması

Pilotluk ehliyetlerinin çok kolay verilmesi

Pilotluk mesleğinin önemi ve zorluğu

Pilotun kaza yapılan pisti pas geçmemesi

Pilotun uçağın kontrolünü kaybetmesi

S1k yaşanan uçuş iptalleri

Uçağın inişlerinin sert olması

Uçağın İniş takımlarının kötü olması

Uçaklar 304 otobüsten farksız

Uçaklar çok yıpranmış

Uçaklar değiştirilmeli

Uçaklar yeni ve bakımlı

Uçaklara eklenen ekstra koltukların yolcu kalabalığg yapması

Uçaklarda TV yok müzik dinleyemiyorsun

Uçaklardaki koltuk mesafeleri

Uçakların bakımının zamanında ve yeterli teknik donanıma sahip personeller tarafindan yapılmamas1

Uçakların bakımsız olması

Uçakların çok sallanması

Uçakların denetimsiz(bakım-fiziki durum) olması

Uçakların eski olması

Uçakların güvensiz olması

Uçakların kalitesiz olması

Uçakların küçük ve dar olması

Uçakların pis olması

Uçakların sürekli pistten çıkması

Uçakta Iniş ve kalkışların konforsuz olması

Uçakta karşılamanın olmaması - kötü olması 
Pilotların siyasi söylemleri

Pilotların tecrübe eksikliği ve profesyonel olmaması

Pilotların tedbirsiz ve dikkatsiz olması olması

Yer hizmetleri ekibinin tavırları ve uslubü
Uçuş sırasında aşırı bsınç

Uçuşların güvensiz olması

Uçuşların kötü hava koşullarında bile yapılması

Uçuşların rötarlı gerçekleşmesi

Valizlerin uçuş sonunda kırılması

Yapılan açık kodlamanın ardından analizin ikinci basamağında ortaya çıkarılan açık kodların birbirleriyle ilişkilendirilmesi, benzerlerin birleştirilmesi ve yeniden oluşturulmasıyla temalar elde edilmiştir. Tablo 3'de kabin ekibinin hizmet şekli, tavrı ve uslubu temasını oluşturulan kodlar yer almaktadir.

Tablo 3. Örnek Seçici Kodlama Tablosu

\begin{tabular}{c}
\hline Kabin ekibinin hizmet şekli, tavrı ve uslubu \\
\hline Kabin ekibinin senli- benli konuşması \\
\hline Kabin ekibinin asık yüzlü olması \\
\hline Kabin ekibinin bazıları fazla ukala ve kendini beğenmiş \\
\hline Kabin ekibinin ilgisiz olması \\
\hline Kabin ekibinin özensiz tavırları \\
\hline Kabin ekibinin rahat tavırları \\
\hline Kabin ekibinin saygısız olması \\
\hline Kabin ekibinin çocuk emniyet kemerini dağıtmaması \\
\hline Kabin ekibinin yolculara kötü davranması ve bağırması \\
Uçakta karşılamanın olmaması- kötü olması \\
\hline Kabin ekibinin yolcuyu aşağılaması - terslemesi
\end{tabular}

Analizin son aşamasında seçici kodlama yapılmıştır. Seçici kodlamada analizin ilk iki sürecinin sonunda ortaya çıkarılan temalar kapsamında kullanıcı yorumlarının yeniden taranması ile temaların birleştirilmesi sağlanmış ve sonuçta kategoriler oluşturulmuştur. İlk basamağı açık kodlama olan ve son basamakta seçici kodlama ile biten bu kodlama süreci sonunda ortaya çıkarılan kodların, temaların ve kategorilerin sayıları tablo 3'de verilmiştir.

Tablo 4. Analiz Sonucu Oluşturulan Kod, Tema ve Kategori Sayıları

\begin{tabular}{l|c}
\hline & Toplam \\
\hline Kod & 137 \\
\hline Oluşan Tema & 42 \\
\hline Kategori & 10 \\
\hline
\end{tabular}

Çalışmada oluşan açık kodlama neticesinde oluşan kod sayısı 137'dir. Kodların temalaştırılması ile 42 tema oluşmuş ve bu 42 temada 10 kategori başlığında toplanmıştır. Bu bağlamda oluşan kategoriler ve temalar aşağıda verilmiştir. 
Tablo 5. Oluşturulan Kategoriler ve Temalar

\begin{tabular}{|c|c|}
\hline Uçağa, uçuşa ve uçuş ekibine yönelik yorum & Önceki kullanıcı deneyimleri \\
\hline Kabin ekibinin hizmet şekli, tavrı ve uslübü & Bagaj sorunları \\
\hline Kabin ekibinin eğitimi & Güvenlik ve hizmet sorunları \\
\hline Uçağın sosyal ve fiziki imkanları & Rötarlı ve iptal edilen uçuşlar \\
\hline Uçakların bakımı ve denetimi & Boardingden dolayı uçağa alınmama \\
\hline Yer hizmetlerinin kalitesizliği & Kaza sonrası duruma ilişkin yorum \\
\hline Uçuşlarda yaşanan iptaller ve gecikmeler & Kazazedelerin transferi ve tazminat ödemeleri \\
\hline Uçuş konforu ve güvenliği & Kaza sonrası uçağın fiziki durumu \\
\hline Pilotların seçimi ve eğitimi & $\begin{array}{c}\text { Kazaya yönelik açıklamalar ve yayınlanan özür } \\
\text { mesajı }\end{array}$ \\
\hline Pilotların tecrübesizliği ve yanlış kararları & Kaza raporu \\
\hline Pilotların kriz yönetimi & Kazaya yönelik yorum \\
\hline Pilotların siyasi söylemleri & Olumsuz hava koşulları \\
\hline Uçakların modelleri & Hava alanının fiziki şartları \\
\hline Fiyat politikasına yönelik yorum & Kule ekibi ve alınan kararlar \\
\hline Uçak içi ikramların ücretli/yüksek fiyatlı olması & Pilot- kule iletişimi \\
\hline Uçuş ekstraları için ödenen yüksek fiyatlar & İşletme yönetimine yönelik yorum \\
\hline Biletlerdeki iptal ve iade ödemeleri & İşletme politikaları \\
\hline Havayolunun önceki kazaları & Finansman politikası \\
\hline 2 yılda 3 . Kazanız & İnsan kaynakları yönetimine \\
\hline Trabzonda gerçekleşen kaza & Yönetimin çalışan denetimi \\
\hline Gelecekteki satın alma niyeti & Hizmet kalitesine yönelik yorum \\
\hline $\begin{array}{l}\text { Gelecek uçuşlardan tercih etmeme ve mevcut } \\
\text { biletlerin iptali }\end{array}$ & Low cost bir havayolu olmasi \\
\hline Markayı boykot etme & Marka yönetimine yönelik yorum \\
\hline Farklı markalar ile kıyaslama & Pazarlama iletişimine yorum \\
\hline Farklı havayolu şirketleri ile kıyaslama & $\begin{array}{l}\text { İşletme sahibi ve üst düzey yöneticileri } \\
\text { eleştirme }\end{array}$ \\
\hline $\begin{array}{l}\text { Olumsuz marka imajına sahip otobüs } \\
\text { işletmelerine benzetme }\end{array}$ & Müşteri ilişkileri yönetimi \\
\hline
\end{tabular}

Tablo incelendiğinde en fazla temaya sahip kategorinin 12 tema sayısı ile "uçağa, uçuşa ve uçuş ekibine yönelik yorum" kategorisi olduğu görülmektedir. 2. sırada ise 6 tema sayısı ile "İşletme yönetimine yönelik yorum" kategorisi gelmektedir. Son sıralarda ise 2 tema sayısı ile "havayolunun önceki kazaları", "gelecekteki satın alma niyeti” ve "farklı markalar ile kıyaslama" kategorileri yer almaktadır.

\section{SONUÇ VE ÖNERILER}

Bir ürüne, hizmete veya markaya yönelik işletmelerin yaptığı pazarlama iletişiminden daha güçlü, güvenilir ve etkileyici olan tüketicilerin o ürüne, hizmete veya markaya yönelik yaptıkları yorumlar ve birbirleri ile ağızdan ağıza iletişimleridir. İletişim teknolojileri ve internet sayesinde ortaya çıkan elektronik ağızdan ağıza iletişim ise zaman ve mekandan bağımsız olarak milyonlarca tüketicinin birbirleri ile etkileşimini sağlayarak bilgi aktarımını kolaylaştırmaktadır. Bu iletişimle birlikte tüketiciler bir markaya ilişkin fikir sahibi olabilmekte ve zihinlerinde ilgili markaya ilişkin imaj ve beklentiler oluşmaktadır. Her marka tüketicilerin iletişim içeriğinin ve yorumların olumlu olmasını ister ancak bu pek mümkün değildir. Bu bağlamda markaların işletme itibarlarını korumaları ve 
olumlu bir imaj oluştururak rakebette öne çıkmaları noktasında elektronik ortamda tüketici geri bildirimlerini takip etmeleri, iyi analiz etmeleri ve hatta ileri düzeyde de yönetebilmeleri önem arz etmektedir.

Çalışmada markaların yaşadığı olumsuz bir durumun e-wom'e etkilerini tespit etmek amacıyla Pegasus'un yaşadığı uçak kazası sonucunda özür metnini yayınladığı İnstagram gönderisine yapılan tüketici yorumları analiz edilmiştir. Yapılan analizle tüketici yorumlarının \%41,4'ü olumsuz, \%30,5 tarafsız, \%22,2' si destekleyici ve \%5,9 ise farklı bir duruma ilişkin yapılmış yorumlardır. Yapılan yorumların konu ile ilişkisi büyük ölçüde örtüşmektedir. Ancak burada dikkat çeken unsurlardan biri tüketicilerin markaya ilişkin yaşadıkları olumsuz deneyimler farklı bir durum söz konusu olduğunda da gündeme gelmektedir. Bu durumda tüketicilerin markaya ilişkin yaşadıkları olumsuz deneyimleri olumlu deneyimlere kıyasla daha fazla birbirlerine aktardıkları teorisini desteklemektedir. (Smith ve Vogt, 1995; Zeelenberg ve Pieters, 1999; Helm, 2000; Dye, 2000; Dobele, Toleman ve Beverland, 2005)

Aynı zamanda bu sonuçlar markanın yaşadığı olumsuz durumlarda e-wom'in de olumsuz olduğunu göstermektedir.

Çalışma sonucunda e-wom'da öne çıkan konuların başında gönderi konusuna ilişkin yapılan yorumlar gelmektedir. Bunun hemen ardından tüketiciler genel anlamda marka yönetimi ve işletme yönetimine yönelik olumsuz yorumlarda bulunmuşlardır. $\mathrm{Bu}$ yorumlarda işletme politkalarından, hizmet kalitesine, insan kaynakları yönetiminden, müşteri ilişkilerine ve şikayet yönetimine kadar bir çok alana yönelik eleştiriler bulunmaktadır. Yorumların farklı içeriklerde olması e-wom'un işletmenin pazar araştırması, hizmet kalitesinin daha iyi hale getirilmesi, işletme itibarının inşası ve güçlendirilmesi, çalışan performansının değerlendirilmesi, iş performansı, şikayet yönetimi gibi farklı konuları içermesi (Hsu, 2012; Yacouel ve Fleischer, 2012; Browning, So ve Sparks, 2013; Levy, Duan ve Boo, 2013; Mauri ve Minazzi, 2013; Nieto, Hernández-Maestro ve Muñoz-Gallego, 2014; Inversini ve Masiero, 2014; Xie, Zhang ve Zhang, 2014) ile uyum göstermektedir. Bu da araştırma sonucunun literatürde e-wom'un etkili olduğu konularla ilişkili olduğunu göstemektedir. Bu sonuç aynı zamanda e-wom'un işletme itibarında ve marka imajında da etkili bir unsur olduğunu desteklemektedir.

Dikkat çeken bir diğer husus da tüketicilerin markanın düşük maliyet stratejisini benimseyen bir havayolu olmasından dolayı uyguladığı fiyat politikasına yönelik yorumların çokluğudur. Analizle tüketicilerin markayı rakipleri ile kıyasladığı ortaya çıkarılmıştır. Tüketiciler gönderi konusundan bağımsız olarak, markayı rakipleri ile kıyaslayarak veya kötü itibara sahip markalara benzeterek olumsuz yorumlarda bulunmuşlardır. Bunun yanında tüketicilerin markaya ilişkin yaşadıkları olumsuz deneyimlerini konudan bağımsız da olsa markayı zedeleyici şekilde aktarmaları Sundaram vd., (1998)'nin oluşturdukları işletmeden intikam alma kategorisiyle uyum sağlamaktadır. 
“Markaların yaşadığı olumsuz durumlarda tüketiciler markayı desteklemekte midir?” araştırma sorusu kapsamında yorumların sinıflndırılmasında destekleyici kullanıcı yorumu kategorisi oluşturulmuş ve bu kategorinin \%22,2'lik bir orana sahip olduğu ortaya çıkmıştır. Bu noktada tüketicilerin markaların imajını zedeleyen olaylar karşısında daha çok olumsuz ve tarafsız yorumlar yaptığı markayı destekleyici yorumların geri planda kaldığı ortaya konmuştur.

Sonuç olarak baktığımızda işletmelerde yaşanan olumsuz durumlar tüketicilerin ağızdan ağıza iletişimini olumsuz etkilemektedir. İşletmenin yaşadığı olumsuz olaylarda genel anlamda tüketicilerin durumla ilişkili veya ilişkisiz olarak olumsuz ve markayı karalayıcı yorumlarda bulunduğu görülmüştür. Marka imajını zedeleyen bu olumsuz durumlar karşısında tüketiciler, hem mevcut durumu, hem geçmiş deneyimlerini hem de gelecekteki satın alma niyetlerini e-wom'a yansıtmışlardır. Bu noktada markaların görevi sürdürülebilirliklerini sağlamak, rekabet avantajı elde etmek, marka imajını ve itibarını korumak için tüketicilerin milyonlarca kullanıcıya ulaşan elektronik ağızdan ağıza iletişim süreçlerini iyi takip ederek analiz etmek ve hatta mümkünse uzun vadede bu süreçleri yönetebilir olmaktır. 


\section{KAYNAKÇA}

Akar, E. (2010). Sosyal medya pazarlamast: Sosyal webde pazarlama stratejileri. Ankara: Efil Yayınevi

Amblee, N., \& Bui, T. (2008). Can brand reputation improve the odds of being reviewed online? International Journal of Electronic Commerce, 12(3), 11- 28.

Ashley, K., \& Tuten, T. (2015). Creative strategies in social media marketing: An exploratory study of branded social content and consumer engagement, Psychology and Marketing, 32(1), 1527

Bajpai, V. Pandey, S., \& Shriwas, S. (2012). Social media marketing: Strategies ve its impact. International Journal of Social Science ve Interdisciplinary Research, 1(7), 214-223

BBC (2020, 6 Şubat) Sabiha Gökçen'de Pegasus uçağı pistten çıktı: 3 kişi öldü, 180 kişi yaralandı.Erişim adresi https://www.bbc.com/turkce/haberler-turkiye-51389039

Bowen, G. (Ed.). (2015). Computer-mediated marketing strategies: Social media and online brand communities: social media and online brand communities. London:Igi Global.

Brodie, R. J., Ilic, A., Juric, B., \& Hollebeek, L. (2013). Consumer engagement in a virtual brand community: An exploratory study. Journal of Business Research, 66(1), 105-114.

Browning, V., So, K. K. F., \& Sparks, B. (2013). The influence of online reviews on consumers' attributions of service quality and control for service standards in hotels. Journal of Travel ve Tourism Marketing, 30(1-2), 23-40.

Cheung, C.M., \& Lee, M. (2012). What drives consumers to spread electronic word of mouth in online consumer-opinion platforms. Decision Support Systems, 53(4), 218-225.

Choudhury, M. M., \& Harrigan, P. (2014). CRM to social CRM: The integration of new technologies into customer relationship management. Journal of Strategic Marketing, 22(2), 149-176.

De Vries, L., Gensler, S., \& Leeflang, P. S. H. (2017). Effects of traditional advertising and social messages on brand-building metrics and customer acquisition. Journal of Marketing, $81(5), 1-15$.

Dessart, L., Veloutsou, C., \& Morgan-Thomas, A. (2016). Capturing consumer engagement: Duality, dimensionality and measurement. Journal of Marketing Management, 33(5-6), 399426.

Dobele, A., Toleman, D., \& Beverland, M. (2005). Controlled infection! Spreading the brand message through viral marketing. Business Horizons, 48(2), 143-149.

Dye, R. (2000). The buzz on buzz. Harvard Business Review, 78(6), 139- 146.

Evans, D. (2008). Social media marketing: an hour a day. Indiana: Wiley Publishing.

Ganesh, K. (2018). Portea: Social media applications, G. Heggde Ve G. Shainesh (Eds.).Social Media Marketing Emerging Concept And Applications içinde (s. 195-218). Singapure: Springer Nature

Gensler, S., Volckner, F., Liu-Thompkins, Y., \& Wiertz, C. (2013). Managing brands in social media environment. Journal of Interactive Marketing, 27(4), 242-256.

Güçdemir, Y. (2017). Sosyal medya: Halkla ilişkiler, reklam ve pazarlama (7. Bask1 ). İstanbul: Derin Yayınları

Gürbüz, S. ve Şahin, F (2018). Sosyal bilimlerde araştırma yöntemleri. Felsefe - yöntem - analiz (4. Bask1). Ankara: Seçkin Yayıncılık

Hanna, R., Rohm, A., \& Crittenden, V. (2011). We're all connected: The power of the social media ecosystem. Business Horizons, 54, 265-273

Harrigan, P., Soutar, G., Choudhury, M. M., \& Lowe, M. (2015). Modelling CRM in a social media age. Australasian Journal of Marketing, 23, 27-37. 
Hawkins, D. I., Best, R., \& Coney, K. A. (2004). Consumer behavior: building marketing strategy. Boston: Mcgraw-Hill.

Helm, S. (2000). Viral marketing-establishing customer relationships by'word-of-mouse'. Electronic markets, 10(3), 158-161.

Hennig-Thurau, T., Gwinner, K. P., Walsh, G., \& Gremler, D. D. (2004). Electronic word-ofmouth via consumer-opinion platforms: what motivates consumers to articulate themselves on the internet? Journal of Interactive Marketing, 18(1): 38-52.

Hewett, K., Rand, W., Rust, R. T., \& Heerde, H. J. V. (2016). Brand buss in the echoverse. Journal of Marketing, 80(3), 1-24.

Hsu, Y. L. (2012). Facebook as international eMarketing strategy of Taiwan hotels. International journal of hospitality management, 31(3), 972-980.

Inversini, A., \& Masiero, L. (2014). Selling rooms online: the use of social media and online travel agents. International Journal of Contemporary Hospitality Management.26(2), 272-292

Kaplan, A. M., \& Haenlein, M. (2010). Users of the world, unite! The challenges and opportunities of social media. Business Horizons, 53, 59-68.

Keller, K. L. (2009). Building strong brands in a modern marketing communications environment. Journal of Marketing Communications, 15, 139-155.

Kemp, S. (2020). Digital 2020, Turkey. DataRePortal. Retrieved February 18, 2020, from https://datareportal.com/reports/digital-2020-turkey

Kırcova, İ., ve Enginkaya, E. (2015). Sosyal medya pazarlama. İstanbul: Beta Yayıncıl1k

Kietzmann, J. H., Hermkens, K., McCarthy, I. P., \& Silvestre, B. S. (2011). Social media? Get serious! Understanding the functional blocks of social media. Business Horizons, 54, 241251.

Klein, L. R. (1998). Evaluating the potential of interactive media through a new lens: Search versus experience goods. Journal of Business Research, 41(3), 195-203.

Kutlu, D. ve Ayyıldız, H. (2017). Konaklama işletmelerinde elektronik ağızdan ağıza iletişimin tüketici ve oteller açısından değerlendirilmesi. Turizm ve Araştırma Dergisi, 1(6), 40- 58.

Laboy, F., \& Torchio, P. (2007). Web 2.0 for the travel marketer and consumer. The International Association Of Online Communicators. http://www.sabrehospitality.com/pdf/whitepaper.pdf.

Levy, S. E., Duan, W., \& Boo, S. (2013). An analysis of one-star online reviews and responses in the Washington, DC, lodging market. Cornell Hospitality Quarterly, 54(1), 49-63.

Mangold, W. G., \& Faulds, D. J. (2009). Social media: The new hybrid element of the promotion mix. Business horizons, 52(4), 357-365.

Mauri, A. G., \& Minazzi, R. (2013). Web reviews influence on expectations and purchasing intentions of hotel potential customers. International Journal of Hospitality Management, 34, 99-107.

Morgan, N. J., Pritchard, A., \& Piggott, R. (2003). Destination branding and the role of the stakeholders: the case of New Zealand. Journal of Vacation Marketing, 9(3), 285-299.

Murdough, C. (2009). Social media measurement: It's not impossible. Journal of interactive advertising, 10(1), 94-99.

Nicholls, P. (2003). Viral marketing: Plant a promotional seed that will spread like wildfire. http://www.klixxx.com/stories/features/viral4.html

Nieto, J., Hernández-Maestro, R. M., \& Muñoz-Gallego, P. A. (2014). Marketing decisions, customer reviews, and business performance: The use of the Toprural website by Spanish rural lodging establishments. Tourism Management, 45, 115-123. 
Pan, B., MacLaurin, T., \& Crotts, J. (2007). Travel blogs and the implications for destination marketing. Journal of Travel Research, 46(1), 35-45.

Park, D. H., Lee, J., \& Han, J. (2007). The effect of online consumer reviews on consumer purchasing intention: the moderating role of involvement. International Journal of Electronic Commerce, 11(4), 125-148

Rubin, R. B., Rubin, A. M., \& Piele, L. J. (2005). Communication research: Strategies and sources (6th edt.). Belmont, CA: Thomson/Wadsworth

Safko, L., \& Brake, D.K. (2009), The social media bible, tactics, tools, strategies for business success. John Wileyv \& Sons

Schmitt, B. (2012). The consumer psychology of brands. Journal of consumer Psychology, 22(1), 717.

Smith, R. E., \& Vogt, C. A. (1995). The effects of integrating advertising and negative word-of-mouth communications on message processing and response. Journal Of Consumer Psychology, 4(2), 133-151.

Srinivasan, S., Rutz, O. J., \& Pauwels, K. (2016). Paths to and off purchase: Quantifying the impact of traditional marketing and online consumer activity. Journal of the Academy of Marketing Science, 44, 440-453.

Stateman, A. (2005). Viral marketing, everywhere displays and podcasting: Social and business trends for the new year. Public Relations Tactics, 12(1), 27.

Stephen, A. \& Brat, Y. (2015). Social Media Marketing: Principles and Strategies. Idaho Falls, ID: Stukent

Tafesse, W. (2016). An experiential model of consumer engagement in social media. Journal of Product \& Brand Management, 25(5), 424-434.

Tafesse, W., \& Wien, A. (2018). Implementing social media marketing strategically: an empirical assessment. Journal of Marketing Management, 34(9-10), 732-749.

Tonta, Y. (2009). Information services and Web 2.0: New challenges and opportunities. Electronic Library: 1 International Scientific Conference, Belgrade, September 25th-28th, 2008

Trusov, M., Bucklin, R. E., \& Pauwels, K. (2009). Effects of word-of-mouth versus traditional marketing: findings from an internet social networking site. Journal of marketing, 73(5), 90102.

Weinberg, T. (2009). The new community rules: Marketing on the social web. California : O'Reilly Media Inc

Xie, K. L., Zhang, Z., \& Zhang, Z. (2014). The business value of online consumer reviews and management response to hotel performance. International Journal of Hospitality Management, 43, 1-12

Yacouel, N., \& Fleischer, A. (2012). The role of cybermediaries in reputation building and price premiums in the online hotel market. Journal of Travel Research, 51(2), 219-226

Yıldırım, A. ve Şimşek, H. (2018). Sosyal bilimlerde nitel araştırma yöntemleri (11. Baskı). Ankara: Seçkin Yayıncılık.

Yüksel, A. ve Yüksel, F. (2004). Turizmde bilimsel araştırma yöntemleri. Ankara: Turhan Kitapevi.

Zarella, D. (2010). The social media marketing book. sebastopol. Kanada: O'Reilly Media Inc .

Zeelenberg, M., \& Pieters, R. (1999). On Service delivery that might have been: Behavioral response to disappointment and regret. Journal of Service Research, 2(1), 86-97.

Zhang, J. Q., Craciun, G., \& Shin, D. (2010). When does electronic word-of-mouth matter? a study of consumer product reviews. Journal of Business Research, (63), 1336-1341. 